\title{
The perspective of curriculum in Indonesia on environmental education
}

Prihantoro, C. Rudy $\bowtie$

Graduate School of Education, Jakarta State University, Indonesia (rudy_prihantoro@yahoo.co.id)

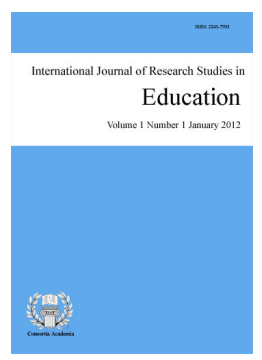

ISSN: 2243-7703 Online ISSN: 2243-7711

OPEN ACCESS

\section{Abstract}

Environmental education is the education activities in the environmental field that are organized by all levels of education. These activities are carried out in a structured and tiered with an integrated curriculum approach and as well as monolithic curriculum. In its implementation, there is a problem related to the low participation of the public to participate in environmental education due to a lack of understanding of the problems of the existing environmental education. The curriculum is a set of plans and arrangements regarding the purpose, content, and teaching materials and methods used to guide the organization of learning in order to achieve certain educational goals". Meanwhile, the 2013 curriculum states that the purpose of the curriculum is the development of the demands, needs and conditions relating to aspects of the community in educational output. The curriculum is designed based competency, that is the outcomes-based curriculum and therefore the development of the curriculum is geared to the achievement of competencies stated in the graduate competency standards. The learning system of the curriculum is based on the active learning approach that encourages students to do observing, questioning, associating, experimenting, and networking. Students are encouraged to find out not to be told (discovery learning). This article discusses environmental education which is set up in the Curriculum 2013 in Indonesia in terms of the broad aspects of the subject matters that are not just about national scope, but the output can meet the challenges of the world.

Keywords: curriculum; environmental education 


\section{The perspective of curriculum in Indonesia on environmental education}

\section{Introduction}

To achieve the educational goals set by the Indonesian government, the curriculum should be strategically arranged and formulated into certain programs because the curriculum is an important issue and curriculum is a part of the educational program. The main objective of curriculum development is to improve the quality of education and is not merely to produce teaching materials. The curriculum does not only pay attention to the development of the present but also directs attention to the future. The purpose of school education is more extensive and complex because it is always in accordance with the changes required. The curriculum should always be updated in line with the changes to keep it relevant to the changing society.

Curriculum development should take into account various aspects such as child development, the development of science, the development society's needs and employments and so on. Curriculum planning should include several aspects including goals, materials, resources, learning activities and evaluation as the basis for establishing the curriculum (Ahmad, 1998, p. 30). One of the things that are important in the curriculum development is the delivery of the contents regarding the environmental issues by incorporating environmental issues into almost all subjects. Based on this, then there is the question on how environmental education is packed into the curriculum, especially in curriculum 2013.

\subsection{Focus of the Research}

Based on the background described, this study focused on the perspective of curriculum 2013 in Indonesia on the environmental education.

\section{Literature Review}

\subsection{Curriculum}

Etymologically, the curriculum comes from the Greek, 'carier', which means the runners and 'curare', which means the race. Thus, the term curriculum is derived from the world of sports in the days of Ancient Rome in Greek, which implies a distance that must be taken by runners from the starting line to the finish line. Furthermore there are some definitions of the curriculum proposed by some experts. According to Taba, curriculum is an instructional design drawn up by considering various things about the learning process and the development of the individual (1962, p. 20), while McNeil adds that curriculum is a learning experience that is planned and directed, that is composed through the process of the systematic reconstruction of knowledge and experience under the supervision of educational institutions so that the learner can continue to have an interest in learning as part of their personal social competence (1984, p. 15). Furthermore, Syaodih asserts that curriculum covers all learning, activities and experiences of the students with the guidance from the school both inside and outside the classroom $(2007$, p.7).

Wayne also confirms that curriculum is defined as all the planned learning spaces given to students by educational institutions and experiences possessed by students when the curriculum is implemented (2007, p. 15). Meanwhile, in Indonesia, with reference to Act No. 20 of 2003 Article 19, verse 1, the curriculum means a set of plans and settings about the objectives, contents and teaching materials, and methods used as guidelines for organizing learning activities to achieve certain educational goals. Thus, the curriculum can be interpreted as a document or a written plan regarding the quality of education that must be possessed by the learners through a learning experience. The document or the written planning contains statements regarding the quality to be possessed of a learner who is listed in the curriculum. The meaning of the quality of education here implies that 
the curriculum is a document that plans the quality of learning outcomes and the educational processes that must be owned and experienced by the learners. The curriculum is the focus of the development process because it describes the ideas of the decision makers that are used as a basis for curriculum development.

\subsection{History of Curriculum Development in Indonesia}

The fast development of an era causes the education to face a daunting challenge, especially in efforts to prepare the next generation that is able to compete in the global era. Such challenges become more complex due to the rapid development of science, technology, and information. All levels of education, starting from early education to higher education, have the duty to prepare the next generation having the good quality. Along with these challenges, the curriculum also needs to be developed according to the needs.

Since 1945, the curriculum has changed several times, namely in 1947, 1952, 1964, 1968, 1975, 1984, 1994, 2004, 2006, and 2013. The development of the curriculum can be mapped into six periods, namely: (1) Curriculum 1975; (2) Curriculum 1986; (3) Curriculum 1994; (4) Curriculum 2004; (5) school based curriculum (SBC) which refers to the National Education Standards, and (6) Curriculum 2013. The following diagram shows the chronological development of the curriculum in Indonesia.

\section{Perkembangan Kurikulum di Indonesia}

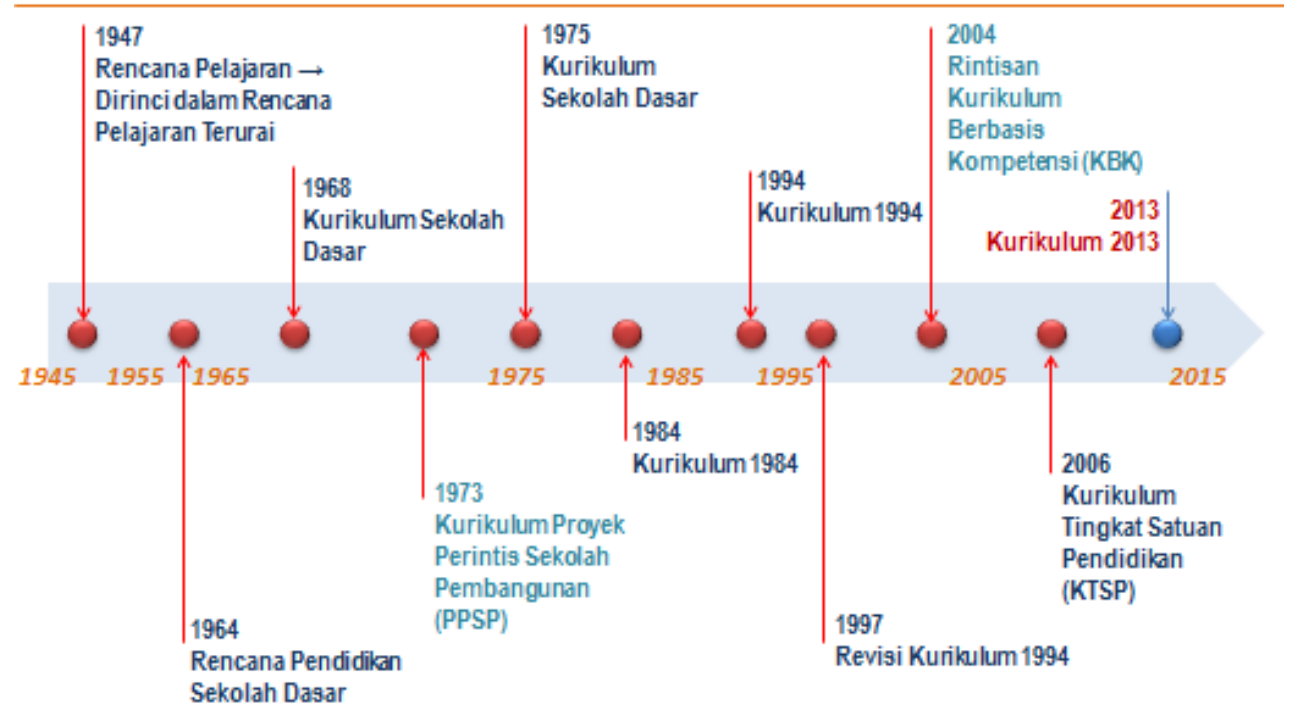

Figure 1

In general, Curriculum 2013 contains four elements of change. They are (1) standard of graduate competencies, (2) standard of contents, (3) standard of learning processes, and (4) standard of assessment.

1. Standard of Graduate Competencies (SKL)

The learners in this regard are expected to improve and to balance between the soft skills and hard skills that include aspects of competencies of attitudes (including: personal faith, morality, self-confident, and responsibility in interacting effectively with the social environment, the natural surroundings, as well as the world and its civilization), skills (including: a person having effective and creative thinking in the realm of the abstract and concrete domains), and knowledge (the ability to produce the persons mastering the knowledge, science, technology, arts, and culture that are based on humanity, national, state, and civilization). 
2. Standard of contents

The competencies which are originally derived from the subjects' turns into a subject are developed from the competencies. Competence is developed through:
a. Integrative thematic in all subjects at the elementary school level (SD)
b. Subjects at the levels of junior high school (SMP) and senior high school (SMA)
c. Vocations at the level of vocational high school (SMK)

3. Standards of learning process
a. Standard process that was initially focused on the exploration, elaboration, and confirmation is fitted with observing, questioning, collecting information, presenting, summing, and creating.
b. Learning does not just happen in the classroom, but also in school and community environments.
c. Teachers are not the only source of learning.
d. Attitudes are not taught verbally, but through example and role model

4. Standard of assessment - Competency-based assessment
a. The shift from assessment through tests (measuring the competence of knowledge based on the results of course) to the authentic assessment (measure all attitude competencies, skills, and knowledge based process and outcome).

b. Strengthening criterion reference assessment, i.e. the achievement of learning outcomes is based on the scores obtained on the position of the ideal score (maximum).

c. Assessment is not only on the level of Basic Competencies (KD), but also the Core Competencies (KI) and Standard of Graduate Competencies (SKL).

d. Encouraging the use of portfolios made up by students as the main instrument of assessment.

From the description, the common thread in curriculum 2013 that can be used for the curriculum development is the standard of processes. Standard of processes that was initially focused on the exploration, elaboration, and confirmation is changed to observing, questioning, processing, presenting, summarizing, and creating. In addition, learning does not only happen in the classroom, but also in the school and the community environment. Thus, teachers are not the only source of learning in the formation of learners' characters, attitude is not taught verbally but through example and role model, including the establishment of living environment awareness.

\subsection{Perspectives of Environmental Education in the Curriculum in Indonesia}

Education is a valuable investment that is grown in order to achieve the dignity of the nation. This is in line with Tilaar's statement that education is a part of people's lives as well as the dynamist of the society itself that become the pillars of the sustainability of community itself (2008, p. 80). Through education institutions someone will get a variety of knowledge and science as well as the skills that will be useful once they learn throughout his life experience. Someone who is educated will have the ability and skill so that a qualified resource will be produced through educational institutions. Thus, education has an important role in delivering a nation to achieve the goals of national development.

One of the efforts to establish the learners to be sensitive to the environment is environmental education. 
The perspective of curriculum in Indonesia on environmental education

Environmental education is expected to change the behavior and patterns of public view towards positively associated with environmental issues and foster a love for the environment early on. The purpose of environmental education can be elaborated into six groups, namely:

a. Awareness - gives encouragement to every individual to gain awareness and sensitivity to the environment and its problems.

b. Knowledge - helps each individual to obtain a wide range of experience and a basic understanding of the environment and its problems.

c. Attitude - helps each individual to obtain a set of values and the ability to get the right choice, as well as develop a sense of environmentally sensitive and provide motivation to participate actively in the improvement and environmental protection.

d. Skills - help individuals to obtain skills in identifying and solving environmental problems.

e. Participation - helps to motivate individuals to participate actively in solving environmental problems.

f. Evaluation - encourages every individual to have the ability to evaluate the environmental knowledge in terms of ecological, social, economic, political, and educational factors (Adisendjaja, 1988).

This is confirmed by Tyler saying that in the process of curriculum development and teaching there are some questions that need to be answered, namely (1) what are the purposes to achieve?, (2) what experiences should be provided to achieve the goal?, (3) how are the learning experiences organized effectively ?, (4) how to determine the successful achievement of the goals? When we refer to the Tyler's opinions, then teaching is not limited to the teaching process to the specific material, but can also be applied in teaching for a field of study/ teaching in schools. Similarly, the curriculum can be developed for a school curriculum or field of study or curriculum for a particular subject.

Therefore, for environmental education in primary and secondary education (general secondary and vocational), the delivery of contents about environmental issues is integratedly outlined in the curriculum system through including environmental issues in almost all subjects. Since 1989/1990 there have been many trainings on population and environment has been introduced by the Ministry of Education and Culture for teachers in elementary, middle and high school as well vocational school. Meanwhile, at the level of higher education at the present time there are study programs for Population and Environment, and Environmental Management.

\section{Methodology of the Research}

The purpose of this research is the environmental education with respect to the set curriculum 2013 in Indonesia in terms of the broad aspects of the study not only of the subjects in the national scope, but the output can meet the challenges of the world. The approach used in this study was a qualitative approach. This was not to test the hypothesis, but to describe the data, facts, and the conditions as they are. The results using a qualitative approach according to Creswell can be used to analyze and predict what should be done in the future and also help to overcome the problems that exist at this time (1998, p. 37).

The method of content analysis as a method of qualitative research was used in this study, and there are six steps that should be implemented, namely (1) formulating a research question, (2) sampling the data sources that have been chosen, (3) manufacturing the category used in the analysis, (4) identifying a sample of documents that have been chosen and coding, (5) designing the scale and items based on specific criteria for data collection, and (6) interpreting the data (Miles \& Huberman, 1994, p. 35). While the data used in the study are words and sentences related to the environment and as a source of data were the curriculum 2013 and some textbooks in 
elementary, junior high school, and senior high school published by the Ministry of Education and Culture of the Republic of Indonesia.

\section{Findings and Discussion}

The findings of this study focus on the perspective of environmental education in the curriculum 2013. At the elementary level, the delivery of environmental issues is through thematic integrative learning methods and integrated with other subjects. Various sciences through experience and habituation are combined into 9 themes that are integrated into lessons like Pancasila and Citizenship Education, Indonesian, Mathematics, Natural Sciences (IPA), Social Sciences (IPS), Cultural Arts and Crafts, and Physical Education. Furthermore, environmental education with an integrated thematic learning method is taught in an integrated manner with other subjects. From 9 themes that have been set out, the themes relevant to the living environment are the second theme "Always Save our Energy" and the third theme "Caring for Life Creatures". The learning materials are presented through interesting stories, in which students are invited to perform activities based on the theme and reading texts. In addition, learners are invited to make habits in daily life. Such habits are not conveyed verbally but should be done so that they can establish good personal with the noble characters.

Furthermore, at the levels of both junior high school and senior high school, the structure of the curriculum describes the conceptualization of curriculum content in the form of subjects. The distribution of content subjects is in a semester or a year; the learning loads for each subject are in a week for each learner. The subject is the smallest organizational unit of basic competence. For the curriculum at secondary school level, the organization Basic Competence is done by considering the continuity between classes and harmony between lessons tied to the Core Competencies. Furthermore, the basic competencies are organized on the basis of the grouping of subjects that must be followed by all students and subjects according to their talents, interests. At the high school level the abilities of students have been focused on specialization in Natural Sciences (IPA) or Social Sciences (IPS).

Every preface of the course books published by the Ministry of Education and Culture of the Republic of Indonesia mention that curriculum 2013 is designed to strengthen the competencies of the learners in terms of knowledge, skills, and attitudes as a whole. Such integrity becomes the basis for the formulation of basic competencies in each subject, so that the basic competencies for each subject include the basic competencies of attitude, the basic competencies of knowledge, and the basic competencies of skills. All subjects are designed to follow such formulation.

The core competence in item 2 of the curriculum 2013 states that learners are required to appreciate and practice honest behavior, discipline, responsibility, caring (mutual assistance, cooperation, tolerance, peace), polite, responsive and pro-active and show such attitudes as a part of the solution to the various problems in interacting effectively with the social environment, living environment, natural environment as well as placing themselves as a reflection of the nation in the world context.

The learning of living environment is integrated in the other subjects. For example, in the craft and Entrepreneurship subjects, the learning activities are designed based on the activities associated with the realm of the real work of craft, technology works, treatment works, and works of cultivation (Curriculum 2013, Kemendikbud). At the treatment and cultivation works, students are required to actively solve the problems in cultivation materials from the in the environment without destructing the environment around the learners, such as from recognizing the cultivation of food crops to packing, treating, and even to the extent of entrepreneurship in the field of cultivation of food (pp. 99-100).

Ross (2006, p. 25) states that entrepreneurship is the ability to create something new in a creative and innovative way in order to obtain the added value. Creative means producing something that has not been in existence before. Innovative means to modify and develop something that already exists, while the added value means having more value than ever. 
The perspective of curriculum in Indonesia on environmental education

Our expectation is all high school graduates in particular have an entrepreneurial spirit. Indonesia is a great nation, a nation that is built on self-reliance, people who are able to sustain themselves without relying on outside parties and are able to compete with other nations. Some examples of food crops that can be used as an example of entrepreneurship are rice, soybeans, peanuts, green beans, sorghum, and corn. Such cultivations are all available in our country, Indonesia. Indonesia is a country rich in natural resources. Indonesia should be able to feed their people. These all can be realized with environmental education taught from primary education up to secondary school through the process of learning through observing, questioning, processing, presenting, summarizing, and creating.

\section{Conclusion}

The perspective of environmental education in the curriculum 2013 is packed with the expectations that learners gain awareness and sensitivity, gain a variety of experience and a basic understanding of the environment, as well as form the character in order to obtain a set of values of environmentally sensitive feeling in the level of basic education up to the secondary education. Thus, students are expected to take part actively in solving problems and protection of the environment by having a polite character.

\subsection{Recommendation}

Environmental education in the curriculum of whatever should be retained due to the constantly evolving the world climate and world climate change that is getting warmer. This thing we need to do in school is not just to give the lessons to students but we make it work through the reforestation activities in the school, we not only fix the infrastructure but also create the condition of the school environment that is green and beautiful so that students can learn with cool conditions and make students able to think clearly, and ready to compete strongly in the global world as entrepreneurs. Save the world... Go green...

\section{References}

Adisendjaja, Y. H. (1988). Understanding the relationship between science, environmental science, and environmental attitudes of student teachers' training college FPMIPA Bandung, Bandung Teachers' Training College [Hubungan antara Pemahaman IPA, Pengetahuan Lingkungan, dan Sikap terhadap Lingkungan dari Mahasiswa FPMIPA IKIP Bandung, IKIP Bandung], Unpublished research report.

Ahmad, H. M. (1988). Curriculum development [Pengembangan Kurikulum]. New York: CV. Faithful Reader. Cresswell, J. W. (2008). Qualitative inquiry and research design. California: Sage Publication. James, S. A., \& Stapp, W. B. (1974). Environmental education. New York: John Willey \& Sons.

McNeil, J. D. (1984). Curriculum: A comprehensive introduction. Los Angeles: University of California.

Miles, M. B., \& Huberman, A. M. (1994). Qualitative data analysis. UK: Sage Publication,

Ministry of Culture and Education of the Republic of Indonesia. (1994). 1994 Basic Education Curriculum and Secondary Education [Kurikulum 1994 Pendidikan Dasar dan Pendidikan Menengah. Departemen Kebudayaan Dan Pendidikan Republik Indonesia].

Ministry of Culture and Education of the Republic of Indonesia. (2013). Curriculum 2013 Basic Education and Secondary Education [Kurikulum 2013 Pendidikan Dasar dan Pendidikan Menengah. Kementerian Pendidikan dan Kebudayaan Republik Indonesia].

Ross, W. E. (2006). The social studies curriculum purposes, problems, and possibilities. New York: State University of New York Press.

Syaodih, N. (2007). Curriculum development theory and practice [Pengembangan kurikulum teori dan praktik]. New York: Rosdakarya.

Taba, H. (1962). Curriculum development theory and practice. New York: Harcourt, Brace \& World, INC.

Tilaar, H. A. R. (2008). National education management [Manajemen Pendidikan Nasional]. New York:

Rosdakarya.

Tyler, R. W. (1975). Basic principles of curriculum and instruction. Chicago and London: University of Chicago. 
Prihantoro, C. R. 